\title{
MEDICINAL WEEDS IN THE RICE FIELD OF KATHMANDU VALLEY, NEPAL
}

\author{
Ram Sharan Dani ${ }^{1}$ and Achyut Tiwari ${ }^{2 *}$ \\ ${ }^{1}$ Department of Botany, Tri-Chandra College, Tribhuvan University, Kathmandu \\ ${ }^{2}$ Central Department of Botany, Tribhuvan University, Kathmandu \\ *Corresponding email: achyutone@gmail.com
}

\begin{abstract}
Weed management in the crop field is one of the major challenges of agriculture. It has been reported that new weeds are encroaching crop fields due to anthropogenic activities such as the use of insecticides, pesticides and chemical fertilizer, and also due to climatic changes including warming temperatures, erratic and unseasonal precipitation, flood and landslides. The agricultural history of Kathmandu valley is quite old, which represents one of the highly productive valleys in of Nepal for agricultural crops including rice, indicating the long history of weeds in the region. There are quite a lot number of medicinally important plants found in rice field as weeds. Traditional practitioners are using these weeds in curing diseases as primary health care, and the utilization of weeds is the best method of weed management. The objective of this present study was to enumerate the weeds in and around paddy field and gather their medicinal properties of weeds among the local people of Kathmandu valley in order to assist with the weed management of paddy field. The periodic field survey was conducted in 9 selected sites, 3 from each district (Kathmandu, Lalitpur, and Bhaktapur) during summer 2012-2014 (two times: crop matured seasons and just after harvesting). We found 104 weed species belonging to 36 families in the rice field of Kathmandu valley that have medicine values.
\end{abstract}

Key words: Kathmandu valley, medicinal plants; rice; weeds

\section{INTRODUCTION}

After the domestication of plants, man has inherited rich traditional knowledge on the use of surrounding plants for different daily activities of life like food, medicine, tannin, dye, resin, fodder, fibres, woods, fuel, cosmetics, and crafts and for religious ceremonies. Cultivation of food plants like rice, wheat, maize is very important for the survival of people contributing as the major source of energy. Rice (Oryza sativa) is one of the predominant cereal crops of Nepal with rice-wheat cropping as a major farming practice. It is cultivated mainly during June-July. Paddy covers about 20 percent of the gross domestic agricultural production forming the supply of more than fifty percent calorie requires for Nepalese people (Basnet, 2004). Although the lowland of Nepal (Terai) alone contributes more than 80 percent rice production in Nepal, rice is cultivated in range of habitats up to the elevation of over $3000 \mathrm{~m}$ asl (NAARC, 2000). Due to the wide range of geographic location of rice, it also includes wide range of weeds that continuously interact with rice plantation challenging the production of the crop.

In agriculture ecosystem, weeds compete with crops for soil nutrients, moisture and light, etc. Weeds are any unwanted plant of the unwanted site and unwanted time, whether native or non- 
native species (Aldrich, 1984). Weeds may become a source of disease and a host of insects or parasites. Literally, every weed is considered as unwanted plant of farmland at unwanted time. Those plants which usually grow where they are not wanted, and usually, interfere with the production of cultivated crops, are considered to be weeds (Ranjit and Bhattarai, 1988). Hence, the weeds are harmful to the crops as they decrease crop productivity by altering soil nutrients or by infecting crops directly. It was mentioned that about 12 percent of crop loss was attributed to weeds (Anaya, 1999). Weeds reduce the crop yield either by reducing the amount of harvestable product (grain, forage) or by reducing the amount of crop actually harvested (Aldrich, 1984). The energy expended for the weeding of man's crops is sometimes more than for any other single human task (Holm, 1971). The weeds cannot harm the crop yield in their low density instead they could stimulate crop growth (Thijssen, 1999). Meanwhile, it is not always true that all weeds are unwanted and harmful plants. Some weeds possess economic values as medicinal, nutrition, industries and fodder forms. Usually, weeds are destroyed during crops seasons by mechanically or by using chemicals or weedicides. It is not always beneficial to remove weeds from crops fields because of their role in nutrient cycling. Several pieces of literature emphasize to establish nutritional relationship between crops and weeds. There are quite numbers of available literatures about medicinal application of weeds (Cunningham, 2001); Dhanam and Elayraj, 2014). Traditional knowledge, practices and identification of medicinally important weeds should be explored to provide medicinal knowledge of weeds, thereby making their maximum use which complements with weed management system in cropland. This work is designed with an objective of identifying the medicinal weeds and documentation of ethnomedicinal uses of weeds present in the paddy fields of Kathmandu valley.

\section{MATERIALS AND METHODS}

\section{Study Area}

Kathmandu Valley lies at 1,300 masl and is located between latitudes $27^{\circ} 32^{\prime} 13^{\prime \prime}$ and $27^{\circ} 49^{\prime} 10^{\prime \prime}$ north and longitudes $85^{\circ} 11^{\prime} 31^{\prime \prime}$ and $85^{\circ} 31^{\prime} 38^{\prime \prime}$ east. Its three districts, Kathmandu, Lalitpur, and Bhaktapur, cover an area of 899 square kilometres, whereas the area of the valley as a whole is 665 square kilometres. The valley is bowl shaped and surrounded by the Mahabharat mountain range on all sides. There are four hills acting as forts of the valley, Phulchowki in the South East, Chandragiri in the South West, Shivapuri in the North West, and Nagarkot in the North East. The highest altitudes are 2,166m (in Bhaktapur), 2,732m (in Kathmandu), and $2,831 \mathrm{~m}$ (in Lalitpur).

The climate is good, the soil is fertile, and is endowed with rich forests and scenic beauty. The climate is subtropical, temperate, and cooltemperate, with four distinct seasons: spring from March to May; summer from June to September; autumn from October to November; and winter from December to February. In general, the annual maximum and minimum temperatures are between $29^{\circ} \mathrm{C}$ in June and $1{ }^{\circ} \mathrm{C}$ in January. The annual rainfall records for Kathmandu from 1995 to 2003 show fluctuations between 1,171 to $1,868 \mathrm{~mm}$.

The valley is surrounded by four major hills viz. Shivpuri, Phulchoki, Naagarjun and Chandragiri. This survey was conducted in the village area of three districts namely Kathmandu (Dahchok, K1; Matathirth, K2 and Sankhu, K3), Lalitpur (Khokana, L2; Badikhel, L3 and Jharuwarashi, L1), and Bhkatapur (Nagdesh-Madhypur, B1; 
Nalinchok, B2 and Chitpol, B3) (Fig. 1).

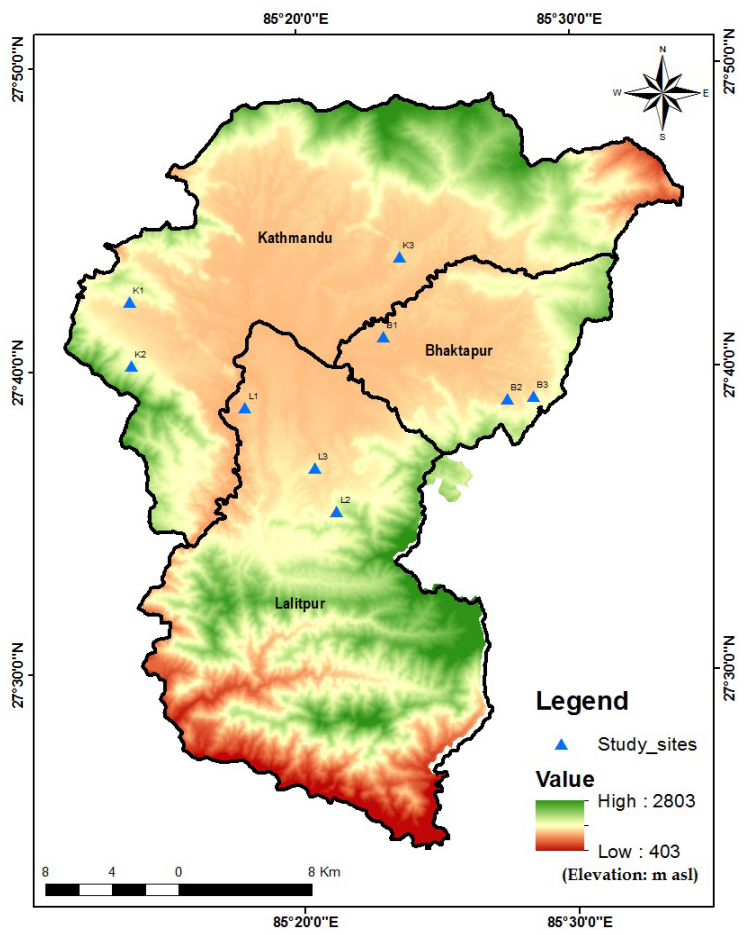

Fig. 1: Map showing Kathmandu valley with selected study area

\section{Methodology}

The study was conducted periodically. Field studies were conducted in summer season in September - October to collect all the weed plants in the flowering stage, due to similar phonological changes in rice. While working on a taxonomic and ethnomedicinal survey of Kathmandu valley, we collected weed plants in rice field and collected medicinal values of collected weeds from local people as well as from existing literature. Observation on habit, habitat, local name and uses were recorded in the field notebooks with the help of local people. Random quadrat method was adopted for studying Phyto socioecological attributes of weeds. We laid down 90 quadrats of 1 x 1 sqm in the studied locations. Plant species were identified in the field with available literature.
Specimens that were not identified in the field were collected, pressed and dried in order to prepare herbarium specimens (Siwakoti and Rajbhandari, 2015). All the collected specimens were reconfirmed with the help of standard literature (Hara et al., 1978, Hara and Williams, 1979; Hara et al., 1982; Stainton, 1972; Polunin and Stainton, 1984; Stainton, 1988, Press et al., 2000) and herbarium study. Nomenclature of the species was followed www.tropicos.org.

Ethnomedicinal information of weeds were compiled from local farmers during field visit and additional information with the help of published literatures like Chopra et al. (1956), Kirtikar (1980a), Kirtikar (1980b), Kirtikar (1981a), Kirtikar (1981b), Malla and Shakya (1984), Anonymous (1989), Tiwari and Joshi (1990), AVS (1994), DPR (1997), Rajbhandari and Joshi (1998), Chauhan (1999), Tiwari and Shrestha (2000), Bhattacharjee (2001), DPR (2001), Rajbhandari (2001), Manandhar (2002), Anonymous (2004), Watanabe et al. (2005), Baral and Kurmi (2006).

\section{RESULT AND DISCUSSION}

We found 104 species of weeds in the rice field of Kathmandu valley belonging to 36 families as medicinal plants. Among them, one is a nonflowering plant and 104 are flowering plants. The dominant plant family is Asteraceae (24 species), followed by Poaceae (8 species), Polygonaceae (6 species), Fabaceae (6 species), Euphorbiaceae (5 species), Cyperaceae (5 species), Amaranthaceae, Caryophyllaceae, Scrophulariaceae (4 species each), Malvaceae, Lamiaceae (3 species each), Verbenaceae, Umbeliferae, Solanaceae, Rosaceae, Plantaginaceae, Lathyraceae, Commelinaceae and Capparidaceae each having 2 species and Acanthaceae, Boraginaceae, Companulaceae, Cannabaceae, Chenopodiaceae, Convolvulaceae, Cruciferae, Geraniaceae, 
Nyctaginaceae, Ophioglossaceae, Oxalidaceae, Pedaliaceae, Ranunculaceae, Rubiaceae and Urticaceae with single species each.

Despite being the major crop throughout Nepal and Kathmandu valley, the diversity of weeds in paddy fields are less explored in Nepal with a preoccupied thought that weeds are useless plants. However, there has been significant progress in study of weeds in Nepal in recent years. The study from Paddy field of Kirtipur region (Kathmandu district) enumerated 52 weed species with the maximum weed density in the month of September (Manandhar et al. 2007). The diversity of medicinal weeds, we have reported from Kathmandu valley is very high in comparison to the paddy field of Tamil Nadu India, from where out of reported 145 species, only 39 of them were medicinally used. The greater number of weeds in the paddy fields of Kathmandu valley was also due to the practice of paddy plantation in drier terraces with the rain fed during summer monsoon, and these terraces after paddy harvest remain barren with full of weeds due to the lack of irrigation. And the higher use value of weeds from Kathmandu could be due to the rich cultural diversity and rich traditional knowledge of use of plants from historical time till today.

Table 1-Enumeration of weeds in the rice fields of Kathmandu valley

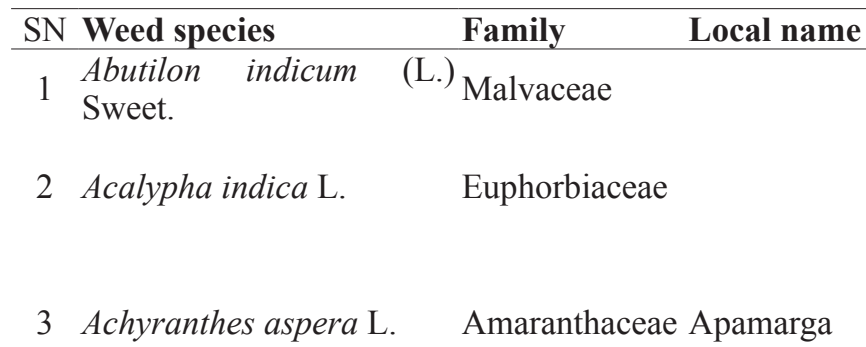

4 Ageratum conyzoides L. Asteraceae Gandhe jhar

5 Ageratum houstonianum Asteraceae Nilo gandhe

Miller jhar

Alternanthera sessilis (L.) Amaranthaceae Bhiringi jhar
R. Br. ex DC.

7 Amaranthus spinosus L. Amaranthaceae Ban lunde

8 Amaranthus viridis $\mathrm{L}$. Amaranthaceae Lunde

9 Ammannia baccifera L. Lathyraceae

10 Artemisia indica Willd. Asteraceae Titepati

Artemisia verlortorum
Lamotte

12 Aster stracheyi Hook f. Asteraceae

\section{Therapeutics applications}

Used in dyspepsia, cough, leucorrhoea, piles, toothache, stomach-ache, tuberculosis.

Used in Asthma, bronchitis, bed sores, earache, tape worm, ringworm, pneumonia, rheumatism, scabies, ulcers, headache,

Used in bleeding piles, bronchitis, cough, dropsy, diuretic, dysentery, dyspepsia, skin diseases, toothache, urinary, concretions, vomiting.

Infusion of the herb is extensively used for curing flatulence, dysentery, colic and other gastrointestinal ailments.

Used to stop bleeding on cut and wounds

Useful in body pain, eye disorders, nutritional disorders, piles, stomach-ache.

Used in colic, eczema, gonorrhoea, menorrhagia.

Used as a blood purifier, digesting agent, piles.

Used as anti-typhoid, anti-tubercular properties, toxic prevention, ringworm, sore, Stomachic, purgative, deobstruent, anthelmintic, Insecticidal, skin diseases, rheumatism, bronchitis, fever, headache Used in Anthelmintic, emmengagoue, leucoderma, appetizer, disease of itching, sweating, amenorrhoea, dysmenorrhoea, cures tumours, antiseptic

An antidote to food poison, contagious fever, headache, cures wounds 


\section{Berleria cristata L.}

Acanthaceae

Bhedekuro

14 Bidens pilosa $\mathrm{L}$.

Asteraceae

Kuro

15 DC.

f.) Asteraceae

Kukur ghans

$16 \begin{aligned} & \text { Blumeopsis flava (DC) Asteraceae } \\ & \text { Gagnep. }\end{aligned}$

$17 \begin{aligned} & \text { Boehmeria clidemioides } \mathrm{Miq} \\ & {[=\text { Boehmeria diffusa } \mathrm{L} .}\end{aligned}$

18 Breea arvensis (L.) Less. [= Cirsium arvense L.] Asteraceae

19 L. Cannabaceae

20 Capsella (L.) Medik.

21 Cassia mimosoides $\mathrm{L}$.

22 Cassia tora $\mathrm{L}$.

Fabaceae

23 Centella asiatica (L.) Urb. Umbeliferae

Godtapre

24 Euphorbia hirta L.

Euphorbiaceae Dudhe jhaar

25 Chenopodium album L.

Chenopodiaceae Bethe Saag

26 Cirsium verutum (D. Don) Spreng.

Asteraceae

Sungure kanda

27 Cleome gynandra L. Capparidaceae Junge phul

28 Cleome viscosa $\mathrm{L}$. Capparidaceae

Ban tori

29 Clerodendrum serratum Verbenaceae (L.) Moon

Chuva, Andekhi

30 Clitoria ternatea L.

Fabaceae

Aparajeeta

31 Coix lachryma-jobi L. Poaceae Bhirkaulo Commelina benghalensis Commelinaceae Kaane jhar Blume

33 Commelina paludosa Bl Commelinaceae Kane saag

34 Convolvulus arvensis L. Convolvulaceae 35 Conyza stricta Wild. Asteraceae
Useful in inflammations, fevers, bronchitis, blood diseases, biliousness, pains and asthma The extract of the plant is applied in Leprosy, tumour, fistulae diarrhea, and other skin disorder by rural peoples

Astringent, anthelmintic, deobstruant, abdominal disorders, liver disorders, hematemesis, cough, bronchitis, cholera, hypertension, tranquiliser

Used in cuts and wounds

Used as Anaemia, asthma, blood purifier, fever, hastens delivery, inflammation of urinary tract, jaundice, muscular pains, ophthalmic, swelling.

Used in indigestion

The leaf part is used in resolving tumours

Astringent, bleeding, most reliable medicine for staying fluxes of blood

Used in Jaundice, scabies, worm control.

The leaf juice is specifically used for ringworm and also useful in curing other skin trouble in the rural area

Used in brain tonic, elephantiasis, leprosy, weakness.

Used in Asthma, boils, bronchitis, cough, colic troubles, enriches the blood, laxative, piles, swellings, vomiting

Used as digestive, aphrodisiac, dyspepsia, decoction, bronchitis, stomach-ache, spleen enlargement

Root paste is given to fever

Used in earache, inflammation, rheumatic, stomach-ache.

Used in cough, dyspepsia, fever.

Used as expectorant, antispasmodic, epilepsy, cough, increase appetite, stimulant, antileech, febrifuge, dyspnoea, cough, catarrhal affections, cephalgia, ophthalmia, dropsy Used for Eye diseases, headache, indigestion, itching, pox, snake bite, warts, worm control. Used in menstrual, disorder, intestinal worms, Diuretics, Pneumonia, Pectoral disease Used in burns, boils, laxative, leprosy, nervous disorders, swellings.

Used in vertigo, Fever, Bilious

Cathartic properties

Cures dysentery and diarrhoea 
36 Crotalaria accicularis Fabaceae

37 Croton bonplandianus Euphorbiaceae

38 Cuphea procumbens L. Lathyraceae Sulpa phul

39 Cynodon dactylon (L.) Poaceae Dubo Cynoglossum zeylanicum

40 (Vahl ex Hornem.) Thunb. Boraginaceae Kanike phul ex Lehm.

41 Cyperus difformis L. Cyperaceae

42 Cyperus iria L.

Cyperaceae

43 Cyperus rotundus $\mathrm{L}$.

Cyperaceae

44 Desmodium gangeticum Fabaceae (L.) DC Asteraceae

45 Dichrocephat

46 Drymaria cordata L. Caryophyllaceae Abhijalo

47 Drymaria diandra Blume Caryophyllaceae Abhijalo

48 Echinochloa colona (L.) Poaceae Sama

$49 \begin{aligned} & \text { Echinochloa crus-galli Poaceae Sama } \\ & \text { (L.) P. Beauv. }\end{aligned}$

50 Eclipta prostrata (L.) L. Asteraceae Bhringraaj

51 Elephantopus scaber L. Asteraceae Gomukhi,

52 Emilia sonchifolia (L.f.) Asteraceae DC. dichotoma Cyperaceae 53 Fimbristy
(L.) Vahl

54 Galinsoga parviflora Cav. Asteraceae

55 Geranium pratense L. Geraniaceae

56 Gnaphalium affine D.Don Asteraceae 57 Hydrocotyle sibthorpioides Umbeliferae
Lam.

58 Imperata cylindrica (L.) Poaceae Beauv

59 Indigofera linifolia (L.f.) Fabaceae Buti jhar

Used in cure scabies, detoxicant.

Used in Arthritis, polio.

Used as anti-typhoid, anti-tubercular properties, toxic prevention, ringworm, sore, Used in dysentery, insanity, leucorrhoea, piles, urinary troubles.

Healing agent for cuts, and wounds, treat ringworm, conjunctivitis, fractures bones, uterine tumours, boils,

Used as diuretic, Astringent, Diarrhoea, Gonorrhoea, Syphilis

Used as stimulant, Stomach-ache, Astringent

Tumour is used in Abscesses, cholera, cough, diarrhoea, epilepsy, fever, wounds, erysipelas,

Used in Asthma, diuretic, eczema, itching,

For nasal infection

Used in headache, antipyretic, cold, throat problem, diarrhoea, dysentery

Used as a laxative, peptic ulcer, cough and cold

Useful in biliousness and constipation and flatulence

Check haemorrhage, disease of the spleen

Antiseptic for ulcers, emetic, jaundice, nerves problems, purgative, tonic, snakebite. Used as cardiac tonic, diuretics, febrifuge, dysuria, diarrhoea, toothache, rheumatism Astringent, opthalmia, gastropathy, diarrhoea, intermittent fever, asthma, antiasthmatic, cuts and wounds

Used in headache

Chitlange jhar Used in a wound to check bleeding

Used as Analgesic, anti-inflammatory, influenza, cough, cold, joint pain backache, eyes, biles, swelling of limbs

Buki phool Used in cut and wounds

Sano Used as a brain tonic, elephantiasis, leprosy, ghodtapre weakness.

Siru Used as antipyretic, diuretic, hypertension, jaundice, wounds

Used for febrile eruption, amenorrhoea 
60 Jatropha gossypifolia L. Euphorbiaceae Sajiwan

61 Lantana camara L. Pedaliaceae Banmara

$62 \begin{aligned} & \text { Leucas plukenetii (Roth) } \\ & \text { Spreng [=Leucas aspera L]. Lamiaceae Ban tulasi }\end{aligned}$

$63 \begin{aligned} & \text { Lindernia oppositifolia } \text { Scrophulariaceae Kankare jhaar } \\ & \text { (L.) Mukerje }\end{aligned}$

64 Lippia nodiflora L. Verbenaceae

65 Lobelia chinensis Lour. Campanulaceae Eklebir

$66 \begin{aligned} & \text { Mazus pumilus (Burm. f.) Scrophulariaceae } \\ & \text { Steen }\end{aligned}$

67 Mazus surculosus D.Don Scrophulariaceae

68 Mentha arvensis L. Lamiaceae $\begin{aligned} & \text { Pudina, } \\ & \text { baabari }\end{aligned}$ 69 Ophioglossum petiolatum Ophioglossaceae Jibre sag
Hook.

70 Oxalis corniculata L. Oxalidaceae Chari amili Persicaria barbata

71 (L.) Hara [Polygonum Polygonaceae Pire, bikha barbatum L.]

$72 \begin{aligned} & \text { Persicaria chinensis (L.) Polygonaceae Seto pire } \\ & \text { H. Gross }\end{aligned}$ Persicaria hydropiper

73 (L.) Spach [=Polygonum Polygonaceae Pire hydropiper L.]

Persicaria perfoliata (L.)

$74 \mathrm{H}$. Gross [Polygonum Polygonaceae Amilo pire perfolium $\mathrm{L}$.]

$75 \begin{aligned} & \text { Phragmites karka (Retz.) Cyperaceae Narkat } \\ & \text { Trin ex Steud. }\end{aligned}$

$76 \begin{aligned} & \text { Phyllanthus amarus } \quad \text { Euphorbiaceae Amala jhar } \\ & \text { Schumach. \& Thonn }\end{aligned}$

77 Plantago erosa Wall. Plantaginaceae Isabgol

78 Plantago major L. Plantaginaceae Isabgol
Useful in convulsion, syphilis, neuralgia, dropsy, pleurisy, pneumonia

Used in cuts, wounds

Used in digestion, fever, head ache, jaundice, stomach disease, snakebite

Chronic bronchitis, mixed with coriander and applied to skin disease, cut and wounds

Used in Asthma, anthelmintic, bronchitis, blood and eye disorders, bowels, burning sensation, fevers, colds, diseases of the heart, stomachic, thirst and loss of consciousness, ulcers, urinary concretions, wounds, vulnerary.

Snake bites, boils, ascites from cirrhosis, schistomiasis, nephritis, oedema, enteritis, diarrhoea

Used cure typhoid

Used in hyperacidity, cut and wounds

Antiseptic, anthelmintic, cardiotonic, febrifuge, Sudorific, Contraceptive, asthma, splenopathy, cough, jaundice, general weakness, rheumatism, fever, bronchitis, skin diseases, wounds and cuts

Used to treat wounds, cuts, nasal bleeding and check vomiting

Used as cooling effect, dysentery, diarrhoea, Stomach troubles.

Astringent, stimulating wash for ulcers, swollen parts of body, scabies, also used as a fish poison

Used and antiscorbutic and tonic

Used as a fish poison, applied in skin disease, stomach-ache

Juice is used in backache

Used as cooling, diuretic and diaphoretic

Used in Jaundice, diabetes, urinary infections, intermittent fever.

In the case of indigestion and boils

Used as diuretics, antidysentric, expectorant, aphrodisiac, habitual constipation, chronic dysentery, colonalgia, gonorrhoea, nephropathy, duodenal ulcers, general debility, gout, diarrhoea, 
79 Polygonum plebeium R. Br. Polygonaceae

80 Portulaca oleracea L. Portulacaceae

Duchesnea indica (Andrews)

81 Focke. [=Fragaria indica Rosaceae Andrew.]

82 Ranunculus laetus Wall. ex Ranunculaceae Naak kore

83 Rosa sericea Lindl Rosaceae Jungali

$84 \begin{aligned} & \text { Rubia manjith Roxb. ex Rubiaceae Majitho } \\ & \text { Fleming }\end{aligned}$

85 Rumex nepalensis Spreng. Polygonaceae Hal-Hale

86 Saccharum $\quad$ Poaceae Ukhu

87 Saccharum spontaneum L. Poaceae Kans

88 Salvia plebeia $\mathrm{R}$. Br. Lamiaceae

$89 \underset{\text { Setaria viridis (L.) P. Poaceae }}{\text { Beauv }}$

$90 \begin{aligned} & \text { Sida cordifolia L.(Burn. f) } \\ & \text { Borss }\end{aligned}$

91 Sida rhombifolia L. Malvaceae Balu

92 Solanum nigrum $\mathrm{L}$. Solanaceae Kali gedi

Solanum surattense Burm.f

93 [= Solanum xanthocarpum Solanaceae Schard \& Wendl.]

94 Sonchus oleraceus L. Asteraceae Dudhe jhaar

95 Spergula arvensis L. Caryophyllaceae Jhyaau jhaar

$96 \begin{aligned} & \text { Spilanthes paniculata Asteraceae Bhuin timur } \\ & \text { Wall. ex. DC. }\end{aligned}$

97 Stellaria media (L.) Vill. Caryophyllaceae Armale jhaar

$98 \begin{aligned} & \text { Taraxacum officinale Asteraceae } \\ & \text { Wigg. }\end{aligned}$
Gulaph

Bethe, balune Used in pneumonia, sore throat, blood dysentery

Used in burns, cardio vascular diseases, cholesterol reducer, fever, diarrhoea, diabetes, headache, ulcers, urinary disorders, wounds.

Relief in profuse menstruation, fever, blemishes on the tongue

Used in stomach-ache, rheumatism, dysuria, asthma, skin trouble, pneumonia, kidney trouble

Used in Jaundice, used to wash the eye, ant treat opthalmia, control menstruation, headache, applied joint pain

Used as antidysentric, astringent, anthelmintic, rejuvenating, leprosy, skin diseases, jaundice, Diarrhoea, Wounds, and cuts, urinary diseases, leucorrhoea, otopathy, febrifuge, efficient blood purifier, ear and eye diseases, snake bite, leucooderma, rheumatic arthritis

Used in sprain, cut and wounds, syphilis, ulcers

Used as laxative, expectorant, cardiotonic, aphrodisiac, bronchitis, anaemia, seminal weakness Used as laxative, emollient, diuretics, lithotroptic, haemostatics, aphrodisiac

Used as antiemetics, cardiotonic, dentrifuge, contraceptive, wounds, cuts, cough, peptic ulcers, splenopathy, dental caries, jaundice, fever and general weakness

\section{Widely used in Bruises}

Astringent, anti-rheumatic, gonorrhoea, leucorrhoea, heal cuts, nervous disorders, snake bite, scorpion sting, and wounds.

Demulcent, diuretic, haemorrhoids, stomach-ache Used in Jaundice, cough, piles, skin diseases, ulcer Used as an anti-inflammatory and in asthma, Bhaise kanda constipation, diuretic, fever, laxative, sore throat, stimulant, cough, stomach-ache, Used in earache, eye diseases, fever, scars, stomach upset.

Used as a fermenting agent

Used in snake bite, toothache, stomach-ache,

As plaster for broken bones and swelling Used as antibacterial, chronic hepatitis, intermittent fever, insomnia, jaundice, biliary calculi and other hepatitis, heart trouble 
99 Torenia asiatica L.

100 Tridax procumbens L.

101 Urtica dioica $\mathrm{L}$.

102 Vernonia cinerea (L.) Less. Asteraceae

103 Viola pilosa Blume.

Violaceae

104 Youngia japonica (L.) DC. Asteraceae
Scrophulariaceae Pidhaa maari The juice is used in cuts and wounds

Asteraceae Kurkure jhaar

Used in boils, cuts, eye diseases, dysentery, diarrhoea, wounds.

Used in diuretics, astringent, anthelmintic, nephritis, haematuria, menorrhagia, jaundice, toothache, emmenagogue

Used in Anthelmintic, cough, fever, Phule jhaar diarrhoea, headache, insomnia, malaria, leucoderma, skin diseases, stomach ache Used for fever, boils, lung trouble, a blood disorder, emetic, emollient and laxative, diaphoretic, antispasmodic and stomachic

Used in indigestion

\section{CONCLUSIONS}

The rich diversity of weeds in paddy fields of Kathmandu valley indicated that the region is one of the potential areas for paddy plantation in Nepal. The higher weed diversity could also be attributed to rich variation in microtopography as well as the farming system of paddy including weeding technique, irrigation system, use of insecticides and pesticides in soil. The entire plant diversity including medicinal plant is threatened due to overexploitation, deforestation and land use changes, more particularly in big cities like Kathmandu. Despite heavy shrinkage in paddy field area in Kathmandu, the weeds are still highly diverse, but their survival could be critically challenged due to rapidly changing climate, emergence of invasive plant species and mainly due to the abandonment of paddy fields from Kathmandu valley.

Since many plants species and their products are used in pharmaceuticals, traditional, indigenous and ethnobotanical knowledge is very important to enhance our capacity to promote the use of weeds plant in primary health care as well as for drug formulation. Widely applied and easy allopathic practices in urban areas are sharply declining, which is highly critical in forming a huge gap in knowledge transfer regarding uses and potentiality of medicinally important plants. The maximum use of locally available weeds from paddy fields is not only environmentally sustained but also highly cheaper against ever-increasing costly antibiotic and other synthetic medicine. Our findings could serve as baseline information for long term study of weed dynamics and be useful for farmers both in terms of weed management in paddy field and use of available weeds for primary health care, and also for people who are working on phytochemistry of medicinal weeds and drug formulation. Further exploration of ecological attributes, traditional knowledge documentation and phytochemical properties of medicinally important weeds are very important to scale up our understanding of weeds and their use as a part of their management technique.

\section{ACKNOWLEDGMENTS}

The authors are grateful to anonymous reviewers for their constructive comments. We would like to acknowledge National Herbarium and Plant Laboratory (KATH, Godabari) and Tribhuvan University Central Herbarium (TUCH, Kirtipur) for the valuable contribution during identification of weed species. We are grateful to Mr. 
Basu Dev Paudel of Central Department of Botany, Tribhuvan University for the preparation of study area map.

\section{REFERENCES}

Aldrich, R.J. (1984). Weed Crop Ecology: Principles in Weed Management. Breton Publishers, North Scituate, MA, USA

Anaya, A.L. (1999). Allelopathy as a tool in the management of biotic resources. Critical Reviews in Plant Sciences. 19: 697-739.

Anonymous, (2004). National Register of Medicinal and Aromatic Plants. IUCN Nepal, Kathmandu, Nepal

Anonymous, (1989). Medicinal Plants in China. Chinese Academy of Traditional Chinese Medicine, WHO Regional Publication, Western Pacific Series No. 2, Manila.

AVS (1994). Indian Medicinal Plants, Arya Vaidya Sala (Vol I-V: a compendium of 500 species). Orient Longman.

Baral, S.R. and P.P. Kurmi (2006). A Compendium of Medicinal Plants in Nepal, Mrs. Rachana Sharma, Maiju Bahal, Kathmandu, Nepal.

Basnet, B.M.C. (2004). Paddy in Nepal. NARC Newsletter (Paddy Special Issue). Communication, Publication and Documentation Division. NARC. Khumaltar, Lalitpur, Nepal. May 2004. p. 4. Bhattacharjee, S.K. (2001). Handbook of Medicinal Plants (Third Edition), Pioneer Publishers, Jaipur, India, 478

Chauhan, N.S. (1999). Medicinal and Aromatic Plants of Himanchal Pradesh, Indus Publishing Company, New Delhi, pp. 632

Chopra, R.N., S. L. Mayor, and I.C. Chopra (1956). Glossary of Indian Medicinal Plants. Council of Scientific and Industrial Research, New Delhi, pp. 330

Cunningham, A. B. (2001). Applied Ethnobotany people. Wild plant use and conservation, Earthscan Publication Ltd., London, U. K.
Dhanam, S., and B. Elayraj (2014). Ethnomedicinal aspects of some weeds from paddy fields of Villupuram district in Tamil Nadu, India International Letters of Natural Sciences. pp 110

DPR. (1997). Medicinal Plants of Nepal (reprint bulletin no. 3), Department of Medicinal, Plants, Thapathali, Kathmandu.

DPR. (2001). Medicinal Plants of Nepal (supplement volume, bulletin no. 10), Department of Medicinal, Plants, Thapathali, Kathmandu.

Holm, L.R. (1971). The role of weeds in human affairs. Weed Science 19: 485-90.

Kirtikar, R.K. and B. D Basu (1981) a. Indian Medicinal Plants (Vol. I), Publisher Lalit Mohan Basu, 49-Leader Road, Allahabad, India, pp. 839.

Kirtikar, R.K. and B.D. Basu (1981) b. Indian Medicinal Plants, Publisher Bishen Singh Mahendra Pal Singh, Dehradun, India, 2: 839-1592.

Kirtikar, R.K. and B.D. Basu (1980) a. Indian Medicinal Plants (Vol. III), Publisher Bishen Singh Mahendra Pal Singh, Dehradun, India, 1593-2393.

Kirtikar, R.K. and B.D. Basu (1980) b. Indian Medicinal Plants, Publisher Lalit Mohan Basu, 49-Leader Road, Allahabad, India, 4: 2395-2793.

Malla, S.B. and P.R. Shakya (1984). Medicinal Plants of Nepal. In: Majupuria, T.C. (ed.) Nepal Nature's Paradise, White Lotus Co. Ltd., Bangkok, Thailand, 261-297

Manandhar, N.P. (2002). Plant and People of Nepal, Timber Press, Oregon, USA

Manandhar, S., B.B Shrestha, H.D. Lekhak (2007). Weeds of Paddy Fields of Kirtipur Kathmandu. Scientific World, 5(5): 100110.

Press, J.R., K.K. Shrestha, and D.A. Sutton 
(2000). Annotated checklist of the flowering plants of Nepal. The Natural history Museum, London.

Rajbhandari, K.R. and R. Joshi (1998). Crop Weeds of Nepal. Natural History Society of Nepal, Kathmandu, Nepal.

Rajbhandari, K.R. (2001). Ethnobotany of Nepal. Ethnobotanical Society of Nepal, Kathmandu, Nepal.

Ranjit J.D. and A.N. Bhattarai (1988). Crop Weeds and Their Control in Nepal. Agriculture Research and Production Project, Winrock International/USAID, Agronomy Division, Khumaltar, Lalitpur, Nepal.

Siwakoti, M. and S. Rajbhandari (2015). Taxonomic Tools and Flora Writing. Department of Plant Resources and Central department of Botany, TU, Kirtipur, Kathmandu, Nepal

Thijssen, R. (1991). Agroforestry and soil organic matter, about green manure, mulch, decomposition and nutrient release. ICRAF, Nairobi.
Tiwari, N.N. and K.K. Joshi (1990). Medicinal Plants of Nepal. I. J. Nepal Medical association28:181-190. II. 28: 221-232. III. 28: 266-279.

Tiwari, N.N. and K.K. Shrestha (2000). MAPDON - Medicinal and Aromatic Plant Database o Nepal. In: Proceedings of NepalJapan Joint Symposium on Conservation and Utilization of Himalayan Medicinal Resources, Department of Plant Resources, Kathmandu.

Watanabe, T., K.R. Rajbhandari, K.J. Malla, and S. Yahara (2005). A Hand Book of Medicinal Plants of Nepal, Kobfai Publishing Project, Foundation for Democracy and Development Studies, Bangkok.

Received 14 May 2018

Revised Accepted 30 August 2018 